\title{
П.Н. ГОРДЕЕВ
}

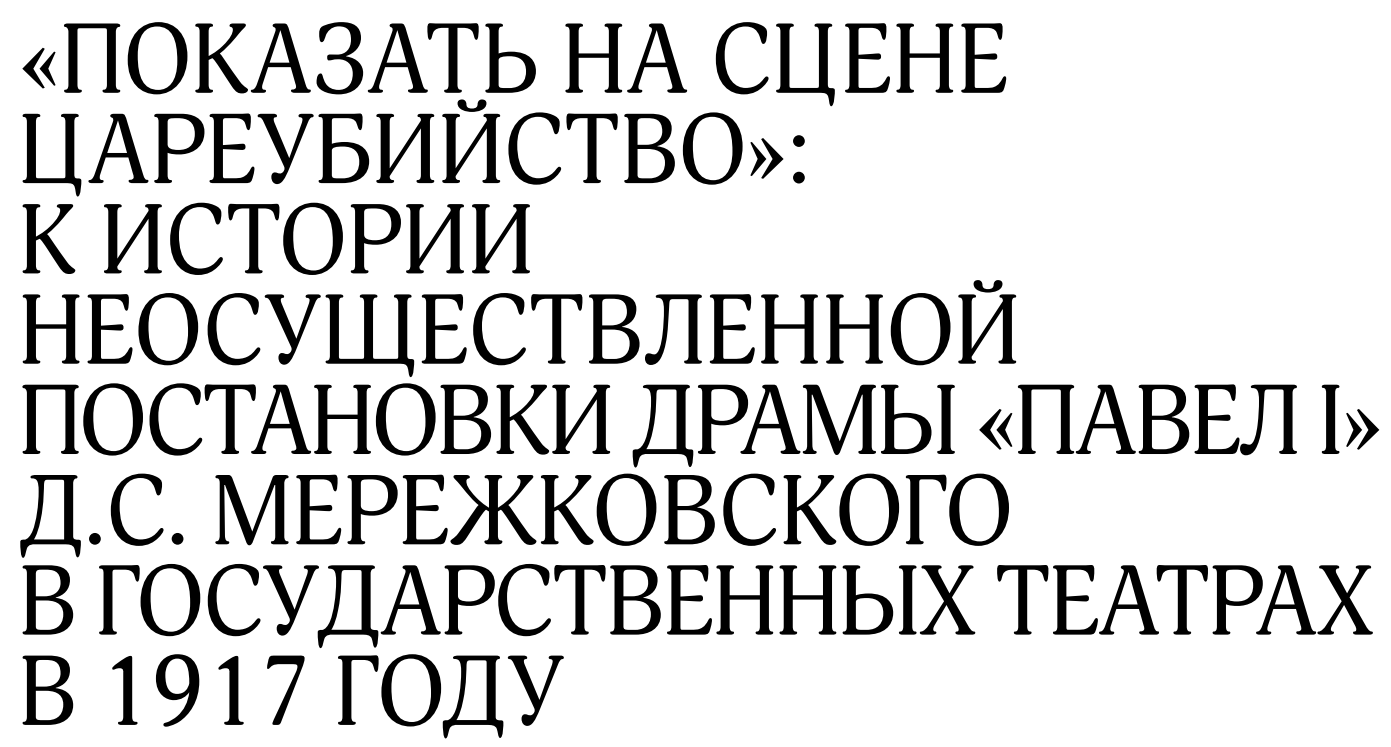

\section{Петр Николаевич Гордеев,}

Российский государственный педагогический университет им. А.И. Герцена, факультет социальных наук, доцент, докторант, кандидат исторических наук e-mail: petergordeev@mail.ru Набережная реки Мойки, д. 48, Санкт-Петербург, 191186, Россия

Исследуется история несостоявшейся постановки драмы «Павел I» Д.С. Мережковского в государственных театрах в 1917 году. Установлено, что, от уже решенной, казалось бы, постановки отказались по ряду причин, среди которых - крупные затраты на премьеру, продажа автором прав на пьесу другим театрам, а также «бестактность» $u$ «несвоевременность» представления на сиене драмь, изображавщей изареубийство.

ключевые слова: Д.С. Мережковский, «Павел I», государственные театры России, революция 1917 года.

Для цитирования: Гордеев П.Н. «Показать на сцене цареубийство»: к истории неосуществленной постановки драмы «Павел I» Д.С. Мережковского в государственных театрах в 1917 году // Обсерватория культуры. 2016. Т. 1. № 1. С. 70-77.

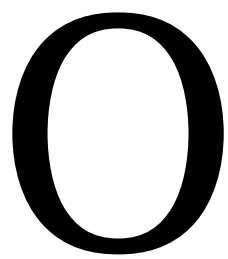

дной из проблем, с которой столкнулись после Февраля 1917 г. бывшие императорские театры, называвшиеся теперь государственными, явилось отсутствие в их репертуаре пьес революционного характера. Сразу после падения монархии, когда актеры Александринского театра «заговорили о более “свободном" репертуаре», то «оказалось, что ставить нечего», так как «русские драматурги писали, приноравливаясь к требованиям цензуры» [1]. В печати стали раздаваться предложения прежде всего ставить пьесы, «запрещенные к представлению <...> царизмом» [2]. Из всех произведений такого рода наибольшее внимание и артистов, и рецензентов привлекла к себе драма Д.С. Мережковского «Павел I». Увидевшая свет еще в 1908 г., она вызвала в свое время уголовное преследование автора по обвинению в «дерзостном неуважении к Верховной власти» (закончившееся оправданием) и никогда ранее не ставилась в России полностью не только в императорских, но и в частных театрах (была осуществлена лишь домашняя постановка в особняке баронессы В.И. Икскуль фон Гилленбанд) [3, 4]. После Февральской революции эту драму, окруженную ореолом цензурного запрета, ожидало, казалось, блестящее будущее: целый ряд государственных и частных театров объявили о намерении поставить 
произведение Мережковского на сцене, а критики заговорили даже о начавшейся «эпохе “Павла I"» [5-7].

Еще в начале марта в «Биржевых ведомостях» появилось сообщение о том, что «в театральных кругах возникла мысль о постановке драмы Мережковского “Павел I". Возможность такой постановки обсуждается как режиссурой государственных, так и частных театров» [8]. Сам автор «решил не отдавать ее в исключительное пользование какого-либо одного театра»; в то же время он «выразил пожелание, чтобы пьеса его была поставлена в Александринском театре раньше, чем в других театрах» [9]. Драматург, настойчиво пытавшийся в то время упрочить положение своих творений на казенной сцене ${ }^{1}$, предпринял с целью скорейшей постановки «Павла I» определенные шаги. Писательница С.И. Смирнова-Сазонова, хорошо знакомая с заведующим репертуаром Александринского театра Н.А. Котляревским, отметила в дневнике 9 марта: «Мережковский звонил к Нестору [Котляревскому. - П. Г.], предлагая поставить своего “Павла" - на [так в тексте. - П. Г.] Александрин[ском] театре. Нестора это покоробило. Не успели свергнуть царя, к[ак] уже предлагают показать на сцене цареубийство, да еще в императорск[ом] театре, вчера только переименованном в государственный» [11, л. 167-168]. Двумя днями ранее, 7 марта, как следует из дневника Д.В. Философова, Мережковский лично посетил Петроградскую контору государственных театров - возможно, также с целью определить сценическую судьбу «Павла I» [12, с. 199].

У именитого автора были и другие рычаги для продвижения своей пьесы на сцену Александринского театра. Во-первых, он являлся одним из четырех членов Петроградского отделения Театрально-литературного комитета, рекомендовавшего те или иные произведения к постановке на императорской сцене [13, л. 1-15]. Во-вторых, писатель мог рассчитывать на личное знакомство с руководителями Комиссариата Временного правительства над бывшим Министерством двора (также, как и он сам, принадлежавшими к масонству): помощником комиссара П.М. Макаровым (обсуждавшим с Д.В. Философовым 6 и 7 марта 1917 г. кандидатуру комиссара над бывшим Министерством двора) и комиссаром Ф.А. Головиным (участвовавшим 29 марта в собрании театральных деятелей на квартире Мережковских, посвященном выбору будущего «комиссара театров») [12, с. 198-199; 14, с. 148, $150-151,153-154 ; 15$, с. $256-257,509,540]$. О том, что именно от Ф.А. Головина исходило предложение, сделанное труппе Александринского театра, начать новый сезон «Павлом I», имеются указания в целом ряде свидетельств [16-20]. В мемуарах коменданта петроградских государственных театров В.Ф. Безпалова есть любопытное замечание, проли- вающее свет на дальнейшее прохладное отношение александринцев к пьесе: «Это распоряжение почиталось некоторыми прямым оскорблением труппы, желавшей во всем самоуправляться» [19, с. 57]. Сам Головин по данному поводу высказывался неопределенно: на просьбу корреспондента «Петроградского листка» прокомментировать слухи о том, что «будущий сезон в Александринском театре откроется пьесой Д.С. Мережковского “Павел I” , он «подтвердил основательность этих слухов, но, вместе с тем, указал, что окончательного решения по этому поводу еще нет. Вопрос о постановке “Павла I" находится в стадии предположения» [21].

В начале апреля в Александринском театре приступили к подготовительным работам по будущей постановке «Павла I» $[22,23]$. Вскоре, однако, выяснилось, что автор уже продал права на пьесу Малому (Суворинскому) театру. Это вызвало негативную реакцию Репертуарного совета Александринского театра, решившего, на заседании 11 апреля, что, в связи с данным обстоятельством, «гнаться особенно за этой новинкой не приходится, тем более, что она не представляет собой классического произведения» $[17,24,25]$. На заседании того же совета, состоявшемся 9 мая, постановка пьесы Мережковского была все еще «оставлена под вопросом» [26]. В прессе, тем временем, появилась информация, что и финансовые обстоятельства не благоволят премьере - необходимость «шить около 500 новых костюмов и писать восемь новых декораций» заставила администрацию театра в начале лета объявить о том, что долгожданная постановка будет отложена на год [27, 28]. Кроме того, в августе-сентябре в прессе стали появляться упоминания о том, что комиссар Ф.А. Головин, некогда предложивший пьесу александринцам, теперь считает ее «бестактной» в «моральном отношении» и вообще несвоевременной («теперь не момент для постановки пьес из жизни дома Романовых») [29, 30].

Изменение позиции Ф.А. Головина представляется особенно примечательным. С одной стороны, оно могло быть обусловлено нарастанием в стране к началу осени 1917 г. масштабного политического кризиса, радикализацией общественного настроения, когда изображение на сцене монарха могло само по себе спровоцировать «эксцессы» в зрительном зале (как это случилось 9 октября, во время представления в Александринском театре «Смерти Иоанна Грозного» А.К. Толстого) [31, с. 31]. С другой - здесь могло сыграть свою роль отношение Головина к арестованной семье Николая II, с бытовой стороной жизни которой он соприкасался с 8 марта 1917 г. - даты своего назначения комиссаром над бывшим Министерством двора. Бывший император и бывший председатель II Государственной думы были лично знакомы с 1907 г., когда они являлись, по сути, политически- 
ми противниками (об этом времени Головин написал в 1912 г. мемуарный очерк, весьма критический по отношению к царю [32, с. $111-128])$. Впрочем, есть основания полагать, что спустя 10 лет Головин смотрел на низверженного монарха более благожелательно; по крайней мере, его помощник и ближайший соратник в 1917 г. П.М. Макаров был «всегда очень предупредителен к Царской Семье», называл Николая II «Вашим Величеством» и всячески стараясь смягчить участь арестованных [33, c. 339; 34, л. 50]. Именно Макаров сопровождал царскую семью в поездке в Тобольск, куда ее увозили в том числе из-за опасения расправы над узниками со стороны царскосельского или петроградского гарнизона. Эти соображения и могли подтолкнуть Ф.А. Головина к мысли о «бестактности» представления цареубийства на подмостках государственных театров.

Итог несостоявшейся сценической истории «Павла I» в Александринском театре подвел сам Д.С. Мережковский в обширном интервью сотруднику «Петроградского вестника» (бывший «Петроградский листок»), появившемся в печати уже в ноябре 1917 года. Отвечая на вопрос, почему пьеса не пошла в итоге ни в Александринском, ни в Малом (Суворинском) театре, драматург сказал: «Мне приходится недоумевать и самому не меньше вас <...> я тоже знал, что пьеса идет в двух театрах, теперь она не идет ни в одном. Всего страннее отношение к пьесе дирекции Государственного театра. Я имел только одну короткую фразу: “Пьеса не пойдет”. - Почему? "Потому что нет тридцати тысяч, которых потребовала бы ее постановка”». После этих слов, по словам Мережковского, он «повесил трубку. О чем мне еще было говорить? О том, что театр, несомненно, располагает декорациями и костюмами, если не подлинно павлова века, то времени очень к нему близкого? Ведь, например, “Холопы” Гнедича - из той же поры. Или о том, что в крайнем случае, пьесу можно играть в сукнах, как играли многие другие пьесы. Или о том, что для зрителя важна пьеса, а не крашеные полотна?» Все это, по мнению писателя, «совершенно понятные истины <...> Вероятно, дело не в этом, а в чем-то другом. Пьеса несвоевременна? Не думаю. Психологически она идет к моменту. Россия только что пережила вариант переворота, подобного тому, что изображен у меня». Намекая тем самым на некие неопределенные обстоятельства, Мережковский делал вывод: «Можно не хотеть ставить пьесу, но нельзя приискать сколько-нибудь резонные и разумные основания к ее отвержению» [35].

Не упомянув в интервью о продаже им авторских прав на постановку «Павла I» Суворинскому театру, писатель, тем не менее, справедливо полагал, что в отсутствии его пьесы в репертуаре Александринки повинны далеко не только финансовые обстоятельства. В отличие от Петрограда, в провале пла- нов московского Малого театра поставить в 1917 г. «Павла I» ведущую роль сыграл именно денежный фактор. Труппа еще в марте наметила эту постановку, что с одобрением отмечалось в прессе [36]. «В наши дни, когда в личности бывшего царя Николая II находят столько родственных черт с его пра-прадедом, рассуждал корреспондент московской «Рампы и жизни» о грядущей постановке в Малом, - драма Мережковского должна возбудить особый интерес» [37]. Однако и этому спектаклю не суждено было состояться. Дальнейшие события представляют любопытный пример переплетения художественных и политических мотивов с ограниченными экономическими возможностями «дома Щепкина».

В середине мая управляющий Малым театром О.А. Правдин в интервью газете «Театр» уверенно (и, как оказалось впоследствии, преждевременно) заявил, что «репертуар предстоящего сезона окончательно утвержден», назвав в числе пьес, которые пойдут в театре впервые, «Павла I» [38]. 17 июня он же отправил уполномоченному по Малому театру ${ }^{2}$ А.И. Сумбатову-Южину выработанный Художественно-репертуарным комитетом план постановок на сезон 1917-1918 гг., а 20 июня официальное ходатайство, в котором, комментируя план, жаловался на сокращение 22 апреля комиссаром Ф.А. Головиным расходов по постановкам с 91000 р. до 66000 рублей. «Если бы эта сумма была ассигнована на постановки только начала будущего сезона, то она, быть может, могла бы несколько устроить нас, - писал Правдин, - но тут оказалось, что с Января 1917 г. по сие время из нее израсходовано уже на постановки прошлого сезона с вечеровыми расходами 25406 руб., значит из всей суммы осталось всего 41000 р.». Приняв эти обстоятельства во внимание, «сопоставляя выработанный Комитетом превосходный репертуар с имеющимися налицо ассигнованиями, мы, то есть я, Режиссерское Управление и Заведующий Постановками, пришли к заключению, что на 41000 р. мы выполнить пожелания Комитета не можем и поэтому тотчас же прибегли к осторожному подсчету расходов на каждую новую постановку до Января нового 1918 г.». Выяснилось, что всего не хватает на исполнение намеченного репертуара около 40000 р., а среди постановок наиболее дорогой являлась как раз премьера «Павла», на которую, «с новой обстановкой, достойной Малого Театра» требовалось «не менее 30000 р.».

Предвидя совет сэкономить на представлении пьесы Мережковского и тем самым выправить имеющийся бюджет, Правдин указывал на художественные задачи возглавляемого им учреждения: «Не считаю лишним указать, что у Государственного Малого Театра имеются в Москве довольно сильные конкуренты, но думаю, что если частное предприятие не боится затрачивать на постановку довольно боль- 
шие суммы ${ }^{3}$, то Национальному Народному Институту [так в тексте. - П.Г.] перед ним срамиться не приходится. Конечно, вычеркнуть ту или другую пьесу из репертуара - это дело одной секунды, но считаю своей обязанностью, как Председатель Репертуарно-Художественного Комитета, указать, что над выработкой представленного репертуара Комитет трудился $2 \frac{1}{2}$ месяца, и репертуар этот так спланирован и так урегулирована в нем вся параллельная работа артистов, что малейшая выемка из него какой бы то ни было пьесы нарушит все, так детально и планомерно задуманное». На этом основании Правдин просил «0 назначении нам просимой суммы без сокращений, имея в виду особенно тяжелое и новое положение наше, долженствующее в этот сезон или подтвердить нужность и полезность Государственного Театра, стало быть и его ближайших руководителей, или же желательность ликвидации исторического Национального Института» [41, л. 3-5].

К своему ходатайству Правдин 21 июня приложил личное письмо Южину, уезжавшему в тот день в Петроград, в котором просил «убедить Федора Александровича [Головина. - П.Г.], что мы хлопочем только о деле Государственного Театра». В противном случае артист угрожал уходом с занимаемой должности: «Если опять начнется торг, то лучше пусть меня отпустят. Все это время я работал, как мог и умел, и когда выберут вместо меня кого-либо другого, не откажусь помочь и послужить своим опытом, но брать на себя такую громадную ответственность, когда материально скован по рукам - не хочу и не могу» [41, л. 10 а об. - 10 б]. Южин был солидарен со своим коллегой и в представлении Ф.А. Головину от 22 июня просил утвердить ходатайство Правдина, с тем, чтобы передержка сверх уже отпущенных средств «была покрыта из бюджета 1918-го года», однако комиссар 23 июня наложил на это категорическую резолюцию: «На увеличение кредита на постановки ранее разрешенного не согласен» [41, л. 8-9].

Данное решение вполне соответствовало тому курсу, который провозгласил ставленник Головина в театральном ведомстве, главноуполномоченный комиссара Временного правительства над бывшим Министерством двора по государственным театрам Ф.Д. Батюшков. Последний, ссылаясь на то, что «дороговизна жизни и падение ценности рубля привели к тому, что размеры добавочной приплаты от казны на расходы по театрам почти удвоились», заявил в программной статье, опубликованной в «Речи»: «В той же пропорции, как увеличены оклады, должны быть уменьшены расходы по постановкам» [42]. Вероятно, однако, на отказ в дополнительном ассигновании повлияли не только соображения экономического порядка, но и изменившееся к тому времени отношение Головина к вопросу об уместности постановки пьесы о царе и цареубийстве в охваченной революцией стране, когда судьба арестованной семьи Николая II представлялась весьма неопределенной. Позднее, в начале осени, в прессу просочились сведения о беседе Ф.А. Головина и А.И. Сумбатова-Южина, в ходе которой комиссар изложил мотивы исключения пьесы Мережковского из репертуара Малого театра: «Большие затраты на постановку, “заигранность” пьесы в провинции, конкуренция почти всех московских театров в отношении этой пьесы и, наконец, соображение, что постановка "Павла I" явилась бы в настоящее время бестактностью в политическом отношении...» [43].

После отказа в дополнительном ассигновании надежда артистов Малого театра поставить «Павла I» была похоронена. 25 июня было созвано экстренное собрание Художественно-репертуарного комитета, члены которого, как сообщал Южин в письме к Ф.Д. Батюшкову от 11-24 июля 1917 г., «постановили изъять “Павла I”. Долго я не забуду их лиц... и своего душевного состояния» [44, л. 77 об.] В личном деле О.А. Правдина сохранился черновик его письма к Д.С. Мережковскому, датированного 27 июня, в котором управляющий театром приносил извинения за то, что постановка не состоится («Вы не можете себе представить наше горе и отчаянье, когда мы получили известие об отказе в отпуске кредита. Роли были распределены, все ими заинтересовались, начали вести переговоры с художниками относительно декораций, костюмов и проч. и вдруг такая неожиданность. Ведь на Вашей пьесе мы базировали всю первую половину сезона и отказ в постановке поставил нас в чрезвычайно затруднительное, чуть не безвыходное положение» [41, л. $11-11$ об.]).

Разочарование артистов Малого театра было вполне искренним: 2 июля Ф.Д. Батюшков сообщал из Москвы заведующему постановочной частью петроградских государственных театров С.Л. Бертенсону: «По словам Василевского ${ }^{4}$, Южин и особенно Правдин страшно удручены невозможностью поставить “Павла” $[45$, л. 1]. 5 августа Н.В. Давыдов (бывший председатель Московского отделения Театрально-литературного комитета, переформированного весной 1917 г. в Литературную комиссию при Художественно-репертуарном комитете Малого театра) писал О.А. Правдину: «Насчет “Павла” наслышан и тоже немало поплакался о его кончине для наступающего сезона. Капитальная была вещь в репертуаре!» [46, л. 1 об.].

Рассмотрев, таким образом, фактическую сторону несостоявшейся постановки «Павла I» на казенной сцене, представляется возможным сделать несколько выводов.

Во-первых, следует констатировать необычайную популярность, которой пользовалась пьеса Д.С. Мережковского в 1917 г. в театральном мире. Сюжет, избранный знаменитым писателем, казался 
тогда весьма актуальным и позволял снять проблему отсутствия в театрах «революционного» репертуара. Поэтому в обоих государственных драматических театрах (Александринском в Петрограде и Малом в Москве) «Павел I» был намечен к постановке еще в марте-апреле 1917 года.

Во-вторых, сам Д.С. Мережковский активно способствовал скорейшему включению «Павла» в репертуар Александринского театра, действуя через представителей администрации (Н.А. Котляревского и, вероятно, Ф.А. Головина). Однако писатель допустил ошибку, продав права на постановку своего произведения Суворинскому театру ранее появления его на Александринской сцене. Это охладило отношение александринцев к «Павлу I», что, вкупе с большими затратами на премьеру, недовольством части труппы навязыванием им, «автономным» актерам, пьесы «сверху» и изменившимся отношением комиссара Головина, предопределило откладывание, казалось бы, уже решенной постановки на неопределенное время.

В-третьих, несколько иная ситуация сложилась в Малом театре, артисты которого горячо желали ставить пьесу Мережковского, невзирая на то, монополии на «Павла» они, как и их петроградские коллеги, не имели. В данном случае основная причина того, что постановка так и не состоялась, лежала в финансовой сфере; впрочем, несогласие Ф.А. Головина на выделение дополнительных средств, требовавшихся театру на подготовку премьеры, отчасти было, как и в случае с Александринским театром, обусловлено соображениями политического порядка.

\section{Примечания}

1 Это заметил и А.Н. Бенуа, в дневниковых записях которого в марте 1917 г. содержатся такие пассажи: «В понимании Мережковского это “Министерство театров", и то поскольку оно ставило бы его пьесы» (запись от 10 марта, о судьбе Министерства двора); «Дмитрий Сергеевич мешал своей назойливостью, своим приставанием, чтобы мы с Димой назначили в театр того человека, который ему нужен» (запись от 20 марта, беседа Бенуа с Д.С. Мережковским и Д.В. Философовым) [10, с. 156, 215].

2 Должности управляющего и уполномоченного (последняя была более важной) возникли весной 1917 г. и были закреплены в принятом 13 мая «Временном положении об управлении государственными театрами» [39, с. 157-159].

3 Имеется в виду московский Драматический театр, в котором пьеса была поставлена в сентябре 1917 г. [40].

${ }^{4}$ Имеется в виду Н.А. Василевский, делопроизводитель Московской конторы государственных театров.

\section{Список источников}

1. Театральный курьер // Петроградский листок. 1917. 6 марта. С. 2.

2. Леонидов В. Письмо в редакцию // Театр и искусство. 1917. № 15. C. 241.
3. У рампы // Биржевые ведомости (вечерний выпуск). 1917. 12 апреля. С. 5.

4. Ларин О.Я. Примечание // Мережковский Д.С. Полное собрание сочинений Дмитрия Сергеевича Мережковского. Москва : Товарищество И.Д. Сытина, 1914. T. VI. С. 277-280.

5. «Павел I-й» // Раннее утро. 1917. 11 марта. С. 5.

6. Старк Э. Репертуарные пожелания // Обозрение театров. 1917. 15 апреля. С. 9-10.

7. «Эпоха» Павла I // Петроградская газета. 1917. 28 июня. С. 5.

8. «Павел I» // Биржевые ведомости (утренний выпуск). 1917. 8 марта. С. 7.

9. Зритель. «Павел I». Справка из недавнего прошлого // Биржевые ведомости (утренний выпуск). 1917. 12 марта. С. 7.

10. Бенуа А.Н. Дневник 1916-1918 годов. Москва : Захаров, 2010. $768 \mathrm{c}$.

11. Смирнова-Сазонова С.И. Дневник за 1917 год // Рукописный отдел Института русской литературы РАН. Ф. 285. № 65. Л. 1-287.

12. Философов Д.В. Дневник // Звезда. 1992. № 2. С. $188-$ 204.

13. Протоколы Петроградского отделения Театральнолитературного комитета // Российский государственный исторический архив. Ф. 497. Оп. 10. Д. 1343. Л. 1-75 об.

14. Философов Д.В. Дневник // Звезда. 1992. № 3. С. 147166.

15. Серков А.И. Русское масонство 1731-2000 : энциклопедический словарь. Москва : РОССПЭН, 2001. 1222 с

16. Будущий репертуар Александринского театра // Петроградская газета. 1917. 31 марта. С. 5.

17. Заседание репертуарного совета // Петроградская газета. 1917. 12 апреля. С. 5.

18. Театральное эхо // Петроградская газета. 1917. 1 мая. C. 13.

19. Безпалов В.Ф. Театры в дни революции 1917. Ленинград : Academia, 1927. 136 с.

20. Бертенсон С.Л. Вокруг искусства. Холливуд : [б. и.], 1957. $414 \mathrm{c}$.

21. Беседа с Ф.А. Головиным // Петроградский листок. 1917. 31 марта. С. 4.

22. Театр и музыка // Русская воля (вечерний выпуск). 1917. 6 апреля. С. 4.

23. Театр и музыка // Речь. 1917. 9 апреля. С. 5.

24. Театр и музыка // Русская воля (вечерний выпуск). 1917. 11 апреля. С. 4.

25. Хроника // Обозрение театров. 1917. 13 апреля. С. 14.

26. Государственный академический театр драмы (ГАТЕДР). Протоколы заседаний Художественно-репертуарного комитета и Репертуарного совета Русской драмы // Отдел рукописей и документов СанктПетербургского государственного музея театрального и музыкального искусства. Ф. 67. КП 7042/5 а. Л. 1. (Нумерация листов наша. - П.Г.). 
27. Театр и музыка // Новое время. 1917. 4 июня. С. 29.

28. «Павел I» отложен до будущего года // Петроградская газета. 1917. 16 июня. С. 5.

29. Почему не пойдет «Павел I» // Петроградская газета. 1917. 22 августа. С. 5.

30. Театральное эхо // Петроградская газета. 1917. 17 сентября. С. 9.

31. Золотницкий Д.И. Академические театры на путях Октября. Ленинград : Искусство. Ленингр. отд-ние, 1982. 343 c.

32. [Головин Ф.А.] Записки Ф.А. Головина // Красный архив. 1926. Т. 19. С. $110-149$.

33. Боткина T.E. Воспоминания о Царской Семье // Царский лейб-медик: жизнь и подвиг Евгения Боткина / сост. О.Т. Коваленская. Санкт-Петербург : Царское Дело, 2011. 343 с.

34. Макаров П.М. Воспоминания Макарова П.М. о пребывании царской семьи в Тобольске, о Корниловском мятеже, о беседе с Керенским // Государственный архив Российской Федерации. Ф. Р-5881. Оп. 2. Д. 465. Л. $1-52$.

35. Аякс. У Д.С. Мережковского // Петроградский вестник. 1917. 22 ноября. С. 2.

36. Театрал. Свободный репертуар // Театр. 1917. 1920 марта. С. 6.

37. «Павел 1-й». Д.С. Мережковского // Рампа и жизнь. 1917. № 12. С. 4.

38. Н. Б. Будущий репертуар Малого театра : (Из беседы с О.А. Правдиным) // Театр. 1917. 18-19 мая. С. 8.

39. Гордеев П.Н. «Временное положение об управлении государственными театрами»: история создания, ре- дактирования и обсуждения «театральной конституции» 1917 года // Революция 1917 года в России: новые подходы и взгляды / ред. кол.: А.Б. Николаев [и др.]. Санкт-Петербург : ЭлекСис, 2012. С. 97-166.

40. Зритель. «Павел I» : (В Драматическом театре) // Новости сезона. 1917. 29-30 сентября. С. 3-4.

41. Личное дело Правдина О.А., артиста, управляющего Государственным московским Малым театром // Российский государственный архив литературы и искусства. Ф. 659. Оп. 5. Д. 74. Л. 1-21 об.

42. Батюшков $\Phi$. Ближайшие задачи государственных театров // Речь. 1917. 17 мая. С. 2.

43. Московские вести // Театр и искусство. 1917. № 38. C. 653.

44. Переписка А.И. Сумбатова-Южина с комиссаром временного правительства над бывшим министерством двора и уделов и другими лицами по вопросу организации работы государственных театров, проекты приказа о временном положении об управлении государственными театрами, положения о функциях уполномоченных по Московским государственным театрам и др. материалы по тому же вопросу // Российский государственный архив литературы и искусства. Ф. 878. ОП. 2. Д. 44. Л. 1-124.

45. Батюшков, Федор Дмитриевич. Письмо его к Бертенсону, Сергею Львовичу // Рукописный отдел Института русской литературы РАН. Ф. 468. ОП. 1. № 11. Л. 1-3.

46. Давыдов Н. Письма к Правдину И.А. // Архивно-рукописный отдел Государственного центрального театрального музея им. А.А. Бахрушина. Ф. 217. № 244. Л. 1-2 об. (Нумерация листов наша. - П.Г.).

\section{P.N. GORDEEV}

\section{“TO SHOW THE REGICIDE ON STAGE": THE HISTORY OF THE UNREALIZED PRESENTATION OF THE PLAY "PAUL I" BY D.S. MEREZHKOVSKY AT THE STATE THEATRES IN 1917}

The article explores the history of the failed presentation of the play "Paul I" by D.S. Merezhkovsky at the State theatres in 1917. There is ascertained that the presentation, that seemed to be ready for realization, was declined for a number of reasons, among which there were the huge costs of the premiere, the author selling the rights for the play to other theaters, as well as the "indiscretion" and "impertinence" of presenting on stage such a play depicting a regicide.

Key words: D.S. Merezhkovsky, "Paul I", state theaters of Russia, the revolution of 1917.
Citation: Gordeev P.N. "To Show the Regicide on Stage": the History of the Unrealized Presentation of the Play "Paul I" by D.S. Merezhkovsky at the State Theatres in 1917, Observatory of Culture, 2016, vol. 1, no. 1, pp. 70-77.

\section{About author Petr Nickolaevich Gordeev, Herzen State Pedagogical University of Russia, Faculty of Social Sciences, Department of History, Associate Professor, Candidate for Doctor's Degree, Candidate of Historical Sciences e-mail:petergordeev@mail.ru Moika River nab., 48, St. Petersburg, 191186, Russia}

\section{References}

1. Teatral'nyj kur'er [Theatrical courier], Petrogradskij listok [The Petrograd sheet], 1917, March 6, p. 2.

2. Leonidov V. Pis'mo v redakciju [Letter to editorial], Teatr i iskusstvo [The Theatre and the Art], 1917, no. 15 , p. 241. 
3. U rampy [Near footlights], Birzhevye vedomosti (vechernij vypusk) [The Stock Exchange News (evening edition)], 1917, April 12, p. 5.

4. Larin O.Ja. Primechanie [Footnote], Merezhkovskij D.S. Polnoe sobranie sochinenij Dmitrija Sergeevicha Merezhkovskogo [The Complete Works of Dmitry Sergeevich Merezhkovsky]. Moscow, Tovarishhestvo I.D. Sytina Publ., 1914, vol. VI, pp. 277-280.

5. "Pavel I-j” ["Paul I"], Rannee utro [The Early morning], 1917, March 11, p. 5.

6. Stark Je. Repertuarnye pozhelanija [Repertoire wishes], Obozrenie teatrov [The Review of the Theatres], 1917, April 15, pp. 9-10.

7. "Jepoha” Pavla I [Epoch of "Paul I"],], Petrogradskaja gazeta [The Petrograd newspaper], 1917, June 28, p. 5.

8. "Pavel I" ["Paul I"], Birzhevye vedomosti (utrennij vypusk) [The Stock Exchange News (morning edition)], 1917, March 8, p. 7.

9. Zritel'. "Pavel I”. Spravka iz nedavnego proshlogo ["Paul I". The reference from the recent past], Birzhevye vedomosti (utrennij vypusk) [The Stock Exchange News (morning edition)], 1917, March 12, p. 7.

10. Benua A.N. Dnevnik 1916-1918 godov [Diary 19161918 period]. Moscow, Zaharov Publ., 2010, 768 p.

11. Smirnova-Sazonova S.I. Dnevnik za 1917 god [Diary of 1917], Rukopisnyj otdel Instituta russkoj literatury RAN [The Department of Manuscripts of the Institute of Russian literature of the Russian Academy of Sciences], coll. 285 , no. 65 , pp. $1-287$.

12. Filosofov D.V. Dnevnik [Diary], Zvezda [The Star], 1992, no. 2, pp. $188-204$.

13. Protokoly Petrogradskogo otdelenija Teatral'no-literaturnogo komiteta [Minutes of the Petrograd department of the Theatre and Literary Committee], Rossijskij gosudarstvennyj istoricheskij arhiv [Russian State Historical Archive], coll. 497, aids 10, fol. 1343, pp. 1-75 back.

14. Filosofov D.V. Dnevnik [Diary], Zvezda [The Star], 1992, no. 3, pp. 147-166.

15. Serkov A.I. Russkoe masonstvo 1731-2000: enciklopedicheskij slovar' [Russian Freemasonry 1731 - 2000: Encyclopedic Dictionary], Moscow, ROSSPJeN Publ., 2001, 1222 p.

16. Budushhij repertuar Aleksandrinskogo teatra [Future repertoire of the Alexandrinsky theatre], Petrogradskaja gazeta [The Petrograd newspaper], 1917, March 31, p. 5.

17. Zasedanie repertuarnogo soveta [Meeting of the repertoire council], Petrogradskaja gazeta [The Petrograd newspaper], 1917, April 12, p. 5.

18. Teatral'noe jeho [Theatrical echo], Petrogradskaja gazeta [The Petrograd newspaper], 1917, May 11, p. 13.

19. Bezpalov V.F. Teatry $v$ dni revoljucii 1917 [Theatres during the revolution of 1917]. Leningrad, Academia Publ., 1927, 136 p.

20. Bertenson S.L. Vokrug iskusstva [Around the art]. Hollivud, without publishing house, 1957, $414 \mathrm{p}$.

21. Beseda s F.A. Golovinym [The talk with F.A. Golovin], Petrogradskij listok [The Petrograd sheet], 1917, March 31, p. 4.
22. Teatr i muzyka [Theatre and music], Russkaja volja (vechernij vypusk) [The Russian will (evening edition)], 1917, April 6, p. 4.

23. Teatr i muzyka [Theatre and music], Rech' [The Speech], 1917, April 9, p. 5.

24. Teatr i muzyka [Theatre and music], Russkaja volja (vechernij vypusk) [The Russian will (evening edition)], 1917, April 11, p. 4.

25. Hronika [Chronicle], Obozrenie teatrov [The Review of the theatres], 1917, April 13, p. 14.

26. Gosudarstvennyj akademicheskij teatr dramy (GATEDR). Protokoly zasedanij Hudozhestvenno-repertuarnogo komiteta i Repertuarnogo soveta Russkoj dramy [State academic drama theatre (GATEDR). The minutes of the meetings of the Art and repertoire Committee and of the repertoire council of Russian drama] Otdel rukopisej i dokumentov Sankt-Peterburgskogo gosudarstvennogo muzeja teatral'nogo i muzykal'nogo iskusstva [Department of Manuscripts and Documents of the St. Petersburg State Museum of Theatre and Music Art], coll. 67, KP $7042 / 5$ a, p. 1.

27. Teatr i muzyka [Theatre and music], Novoe vremja [The New Time], 1917, June 4, p. 29.

28. "Pavel I" otlozhen do budushhego goda ["Paul I" was postponed until next year], Petrogradskaja gazeta [The Petrograd newspaper], 1917, June 16, p. 5.

29. Pochemu ne pojdet "Pavel I" [Why "Paul I" will not played], Petrogradskaja gazeta [The Petrograd newspaper], 1917, August 22, p. 5.

30. Teatral'noe jeho [Theatrical echo], Petrogradskaja gazeta [The Petrograd newspaper], 1917, September 17, p. 9.

31. Zolotnickij D.I. Akademicheskie teatry na putjah Oktjabrja [Academic theaters on the ways of October]. Leningrad, Iskusstvo. Leningr. otd-nie Publ., 1982, 343 p.

32. [Golovin F.A.] Zapiski F.A. Golovina [Memoirs of F.A. Golovin], Krasnyj arhiv [The Red archive], 1926, vol. 19, pp. 110-149.

33. Botkina T.E. Vospominanija o Carskoj Sem'e [Memories of the Tsar Family], Carskij lejb-medik: zhizn' i podvig Evgenija Botkina [The Tsar physician: the life and exploit of Eugene Botkin]. Sankt-Peterburg, Tsarskoe Delo Publ., 2011, 343 p.

34. Makarov P.M. Vospominanija Makarova P.M. o prebyvanii carskoj sem'i v Tobol'ske, o Kornilovskom mjatezhe, o besede s Kerenskim [P.M. Makarov's memoirs about the Tsar family in Tobolsk, about Kornilov rebellion, a conversation with Kerensky], Gosudarstvennyj arhiv Rossijskoj Federacii [The State Archive of Russian Federation], coll. P-5881, aids 2, fol. 465, pp. 1-52.

35. Ajaks. U D.S. Merezhkovskogo [With D.S. Merezhkovsky], Petrogradskij vestnik [The Petrograd bulletin], 1917, November 22, p. 2.

36. Teatral. Svobodnyj repertuar [Free repertoire], Teatr [The Theatre], 1917, March 19-20, p. 6.

37. “Pavel 1-j”. D.S. Merezhkovskogo ["Paul I”. By D.S. Merezhkovsky], Rampa i zhizn' [Footlights and life], 1917, no. 12 , p. 4. 
38. N.B. Budushhij repertuar Malogo teatra: (Iz besedy s O.A. Pravdinym) [Future repertoire of the Maly theatre: (From a conversation with O.A. Pravdin)], Teatr [The Theatre], 1917, May 18-19, p. 8.

39. Gordeev P.N. "Vremennoe polozhenie ob upravlenii gosudarstvennymi teatrami”: istorija sozdanija, redaktirovanija i obsuzhdenija "teatral'noj konstitucii" 1917 goda ["Temporary regulations on the management of state theaters": the history of creation, editing and discussion of "theatrical constitution" of 1917], Revoljucija 1917 goda $v$ Rossii: novye podhody $i$ vzgljady [The revolution of 1917 in Russia: new approaches and views]. SaintPetersburg, JelekSis Publ., 2012, pp. 97-166.

40. Zritel'. "Pavel I" : (V Dramaticheskom teatre) ["Paul I": in the Drama theatre], Novosti sezona [The News of the season], 1917, September 29-30, pp. 3-4.

41. Lichnoe delo Pravdina O.A., artista, upravljajushhego Gosudarstvennym moskovskim Malym teatrom [Personal file of O.A. Pravdin, an artist, a manager by the State Moscow Maly theatre], Rossijskij gosudarstvennyj arhiv literatury $i$ iskusstva [Russian State Archive of Literature and Art], coll. 659, aids 5, fol. 74, pp. 1-21 back.

42. Batjushkov F. Blizhajshie zadachi gosudarstvennyh teatrov [Immediate tasks of the State theatres], Rech' [The Speech], 1917, May 17, p. 2.

43. Moskovskie vesti [Moscow news], Teatr $i$ iskusstvo [The Theatre and the Art], 1917, no. 38, p. 653.

44. Perepiska A.I. Sumbatova-Juzhina s komissarom vremennogo pravitel'stva nad byvshim ministerstvom dvora i udelov i drugimi licami po voprosu organizacii raboty gosudarstvennyh teatrov, proekty prikaza o vremennom polozhenii ob upravlenii gosudarstvennymi teatrami, polozhenija o funkcijah upolnomochennyh po Moskovskim gosudarstvennym teatram i dr. materialy po tomu zhe voprosu [A.I. Sumbatov-Yuzhin's correspondence with the Commissioner of the Provisional Government of the former Ministry of the Court and the Apanages and others about the organization of the state theatres work, the draft order of the temporary regulations on the management of state theaters, the regulations on the functions Commissioners of the Moscow State theatres, and others materials on the same subject], Rossijskij gosudarstvennyj arhiv literatury $i$ iskusstva [Russian State Archive of Literature and Art], coll. 878, aids 2, fol. 44, pp. 1-124.

45. Batjushkov, Fedor Dmitrievich. Pis'mo ego k Bertensonu, Sergeju L'vovichu [Batjushkov, Fedor Dmitrievich. His letter to Bertenson, Sergej L'vovich], Rukopisnyj otdel Instituta russkoj literatury RAN [The Department of Manuscripts of the Institute of Russian literature of the Russian Academy of Sciences], coll. 468, aids 1, no. 11, pp. $1-3$.

46. Davydov N. Pis'ma k Pravdinu I.A. [Letters to Pravdin I.A.], Arhivno-rukopisnyj otdel Gosudarstvennogo central'nogo teatral'nogo muzeja im. A.A. Bahrushina [Archives and Manuscript Department of the State Central Theater Museum named after A.A. Bakhrushin], coll. 217, no. 244, pp. 1-2 back.

\section{НОВИНКА}

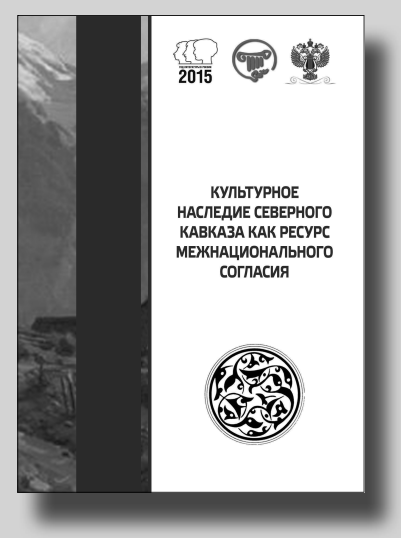

Культурное наследие Северного Кавказа как ресурс межнационального согласия [Текст] : сб. науч. ст. / отв. ред. И.И. Горлова ; редкол. Т.В. Коваленко, Н.А. Костина, А.В. Крюков. Москва ; Краснодар : Принт сервис групп, 2015. 624 с.

В сборник вошли статьи, подготовленные по материалам докладов и сообщений международного научного фрорума «Культурное наследие Северного Кавказа как ресурс межнационального согласия», состоявшегося 3-5 апреля 2015 г. В статьях рассмотрены проблемы культурного наследия народов России в аспекте укрепления российской государственности, основные вопросы теории и практики сохранения культурного и природного наследия, литературное наследие Северного Кавказа в контексте диалога культур, специфические черты этнических культур народов Юга России и механизмы межнационального взаимодействия. Особое внимание уделяется анализу опыта актуализации и репрезентации культурного наследия Северного Кавказа в современном обществе. 